\title{
AGE AND GROWTH OF BASSAN BARBEL, BARBUS PECTORALIS (ACTINOPTERYGII: CYPRINIFORMES: CYPRINIDAE), UNDER CONDITIONS OF A DAM RESERVOIR
}

\author{
Gülnaz ÖZCAN ${ }^{1 *}$ and Süleyman BALIK ${ }^{2}$ \\ ${ }^{1}$ Mustafa Kemal University, Fisheries Faculty, 31200, Iskenderun, Hatay, Turkey \\ ${ }^{2}$ Ege University, Fisheries Faculty, TR-35100 Bornova-Izmir, Turkey
}

Özcan G., Balık S. 2009. Age and growth of bassan barbel, Barbus pectoralis (Actinopterygii: Cypriniformes: Cyprinidae), under conditions of a dam reservoir. Acta Ichthyol. Piscat. 39 (1): 27-32.

Background. Bassan barbel, Barbus pectoralis Heckel, 1843, is widely distributed in the lakes and river systems of Turkey and its neighbouring countries. Bassan barbel is a fish species of commercial value. The aim of this study was to provide necessary biological features of bassan population from Kemer Reservoir.

Materials and Methods. Biological aspects of Bassan barbel were studied based on a total of 206 specimens collected from Kemer Reservoir, during the period December 2004-November 2005. The fish age was determined from scales. Length-weight relation and Fulton's condition factor were used to evaluate fish condition.

Results. The fish were from 1 to 6 year-old. Fork length $(\mathrm{FL})$-weight $(W)$ relations were estimated as $W=0.011 \cdot \mathrm{FL}^{2.980}$ for all specimens studied. The estimated growth parameters of the von Bertalanffy equation were: $L_{\infty}=34.8 \mathrm{~cm}$, $W_{\infty}=549.58 \mathrm{~g}, K=0.168 \cdot$ year $^{-1}$ and $t_{0}=-1.590$ year for all specimens examined.

Conclusion. The fish from Kemer Reservoir were characterized by an average growth rate and it was observed that the specimen grew fast during the first two years of life. The reason why bassan barbel had low condition values is probably because the environmental conditions in the reservoir were poor.

Keywords: bassan barbel, Barbus pectoralis, age, growth, dam reservoir, Kemer Reservoir, Turkey

\section{INTRODUCTION}

Barbus pectoralis Heckel, 1843 is widely distributed in lakes and river systems of the west-, south-, and southeast Anatolia, Syria, Iran, and Iraq (Coad 1991, Geldiay and Balık 2007). Populations of this species are commonly found in a few rivers (Gediz, Bakircay, Buyuk Menderes, Aksu, Goksu, Orontes, Euphrates, Tigris) of Turkey, in rather cool running waters.

Barbus pectoralis (formerly identified as B. capito pectoralis) is one of the nine barbel species inhabiting Turkish freshwaters and it is commonly known in the country as 'biyikli balik'. B. pectoralis can be adapted quite easily to water regime changes. It is a benthopelagic species inhabiting both lentic and lotic environments and it has an economic value since it is commercially fished in reservoirs, lakes, and rivers (Geldiay and Balık 2007). Furthermore, it is a commercially important species also in Anatolia because of its wide distribution, its body size (max $40.4 \mathrm{~cm}, 700.0 \mathrm{~g}$; Çolak 1982) and its tolerance to different environmental regimes.

There are several studies on the biology and ecology of $B$. pectoralis from several water bodies in Anatolia (Balık 1980, Çolak 1982, Ergene 1998, İkiz et al. 1998, Topkara and Balık 2004). In this paper, we provide new information on the age and growth of $B$. pectoralis from Kemer Reservoir. This may contribute to the species conservation and the management of its fisheries in the study area.

Study area. The Kemer Reservoir is located in the city of Aydin, in west Anatolia (lat $37^{\circ} 32^{\prime} \mathrm{N}$, long $28^{\circ} 32^{\prime} \mathrm{E}$ ). The reservoir has an area of $14.75 \mathrm{~km}^{2}$ with a maximum depth of $52 \mathrm{~m}$ (April 2005). It was constructed on the Akcay Stream, one of the important tributary of the Buyuk Menderes River (Fig 1). The reservoir has an oligo-mezotrophic character (Özyalin 2007). The fish species such as: Acanthobrama mirabilis, Chondrostoma meandrense, Capoeta bergamae, Silurus glanis, Carassius gibelio, Lepomis gibbosus, Cyprinus carpio, Petroleuciscus smyrnaeus, and Leuciscus cephalus are also present in Kemer Reservoir.

\section{MATERIAL AND METHODS}

The study was carried out monthly between December 2004 and November 2005 in Kemer Reservoir. The fish were generally caught by gill nets of $18-45 \mathrm{~mm}$ mesh sizes from 8 different stations and depths not exceeding $25 \mathrm{~m}$. Also, cast nets $12-22 \mathrm{~mm}$ mesh size were used to collect specimens from shallow waters $(0-5 \mathrm{~m})$. After the cap-

\footnotetext{
* Correspondence: Dr Gülnaz Özcan, Mustafa Kemal Üniversitesi, Su Ürünleri Fakültesi, 31200, Iskenderun, Hatay, Turkey, phone: +90 326 6141693-317, fax:+90 326 6141877, e-mail: gulnaz.ozcan@yahoo.com,gnarin@mku.edu.tr
} 


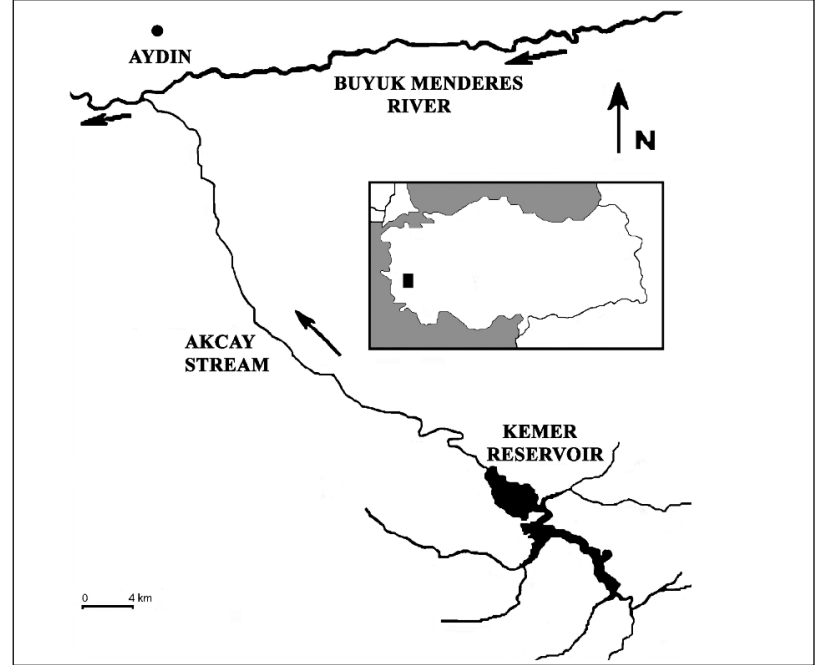

Fig. 1. Map of the study area

ture, the specimens were preserved in $4 \%$ formaldehyde solution. Specimens were measured in the laboratory to the nearest $1 \mathrm{~mm}$ fork length (FL), and weighed to the nearest $0.01 \mathrm{~g}$ total weight $(W)$. Age was determined by macroscopic examination of scales. For this, scales of each specimen (10-15 scales) were removed from the posterior part of the body, cleaned in a $10 \%$ solution of $\mathrm{NaOH}$ and treated according to Chugunova (1963).

Sex of mature specimens was easily determined to the naked eye, while microscopic examination was done for immature specimen. Sex ratios were tested with Chisquared analyses $\left(\chi^{2}\right)$. Fulton's equation was used to calculate the condition factor $(K)$ for each individual: as $K=100 \cdot W \cdot \mathrm{FL}^{-3}$, where FL is the fork length [cm] and $W$ is the body weight [g] (Le Cren 1951). The parameters $a$ and $b$ of the $\mathrm{L}-\mathrm{W}$ relations $\left(W=a L^{b}\right)$ were estimated by the least squares regression method. Confidence intervals of $95 \%$ were calculated for $b$ to see if these were statistically different from 3. An age-length key was constructed and the parameters of the von Bertalanffy growth equation estimated by non-linear least-squares regression. The von Bertalanffy function $L_{t}=L_{\infty}\left(1-e^{-K(t-t o)}\right)$ was used to describe growth in size (for FL), where $L_{t}$ is the length of fish in $\mathrm{cm}$ at age $t ; \mathrm{K}$ is the rate at which the growth curve approaches the asymptote; $L_{\infty}$ is the asymptotic length in $\mathrm{cm}$; and $\mathrm{t}_{0}$ is the theoretical time at which the fish length is zero (Erkoyuncu 1995). For the growth in weight, the same function was used: $W_{t}=W_{\infty}\left(1-e^{-K(t-t o)}\right)^{b}$, where $W_{t}$ is the total weight and $b$ is the power constant of the length-weight relation. Growth performance index $\left(\varphi^{\prime}\right)$ was estimated according to Pauly and Munro (1984).

\section{RESULTS}

B. pectoralis is found in reservoir with a conductivity of $82-603 \mu \mathrm{mhos} \cdot \mathrm{cm}^{-1}$. Water temperature varied between 7.5 and $28.5^{\circ} \mathrm{C}$ in January and August, respectively. Dissolved oxygen content ranged between $6.5 \mathrm{mg} \cdot \mathrm{L}^{-1}$ (August) and $10.1 \mathrm{mg} \cdot \mathrm{L}^{-1}$ (January). $\mathrm{pH}$ values were close to neutral or slightly alkaline. Secchi disc transparency was found to be $1.20 \mathrm{~m}$ in April and $4.10 \mathrm{~m}$ in July.

In total 206 specimen were caught during the study period, in this number 117 males (56.8\%) and 89 females (43.2\%). The fork length of all individuals collected ranged from 9.8 to $27.2 \mathrm{~cm}$ FL (mean $18.5 \pm 3.8 \mathrm{~cm} \mathrm{FL)} \mathrm{and}$ weight from 13.04 to $317.32 \mathrm{~g}$ (mean $96.06 \pm 4.19 \mathrm{~g} \mathrm{~W}$ ) (Table 1). Ages ranged from 1 to 6 years for both sexes. Since mesh size was large (12-45 mm), 0-group fish was not represented in the samples. According to the age-length key, second year class was dominant (31.6\% ) (Table 2).

The overall ratio of males to females was $1: 0.76$. A chi-square revealed significant departure from the theoretical $1: 1$ sex ratio $\left(X^{2}=7.61>X_{1,0.05}^{2}=3.84\right)$. The chisquare test of sex ratios for $B$. pectoralis, divided into age classes, showed that males dominated the second $\left(X^{2}=\right.$ $\left.19.23>X_{1,0.05}^{2}=3.84\right)$, third $\left(X^{2}=3.85>X^{2}{ }_{1,0.05}=3.84\right)$ and sixth $\left(X^{2}=3.85>X_{1,0.05}^{2}=3.84\right)$ age classes (Table 2).

Length-weight relations were calculated for females $(n=89)$, males $(n=117)$ and all specimens $(n=206)$ as: $W=0.011 \mathrm{FL}^{3.068}\left(r^{2}=0.928\right)($ Fig. 2$), W=0.016 \mathrm{FL}^{2.949}$ $\left(r^{2}=0.966\right)$ (Fig. 3), and $W=0.014 \mathrm{FL}^{2.980}\left(r^{2}=0.947\right)$ (Fig. 4), respectively. Isometric growth was observed for females $\left(t=0.77<t_{0.05,87}=1.99\right)$, males $\left(t=0.99<t_{0.05,115}=1.98\right)$ and the whole fish examed $\left(t=0.41<t_{0.05,204}=1.97\right)$.

The von Bertalanffy growth equations were computed as $L_{\infty}=35.7(\mathrm{SE}=0.37) \mathrm{cm}, W_{\infty}=238.0(\mathrm{SE}=35.42) \mathrm{g}$,

Length and weight of Barbus pectoralis from Kemer Reservoir

Table 1

\begin{tabular}{|c|c|c|c|c|c|c|c|c|}
\hline \multirow{2}{*}{ Sex } & \multirow{2}{*}{\multicolumn{2}{|c|}{ Parameter }} & \multicolumn{6}{|c|}{ Age group } \\
\hline & & & $1+$ & $2+$ & $3+$ & $4+$ & $5+$ & $6+$ \\
\hline \multirow{4}{*}{ Male } & fork length & range & $9.8-11.6$ & $11.6-15.6$ & $13.0-26.6$ & $14.1-24.0$ & $16.4-26.0$ & $23.5-26.9$ \\
\hline & {$[\mathrm{cm}]$} & mean $\pm \mathrm{SE}$ & $11.8 \pm 0.52$ & $15.1 \pm 0.29$ & $18.8 \pm 0.46$ & $20.9 \pm 0.42$ & $23.2 \pm 0.71$ & $25.1 \pm 0.29$ \\
\hline & weight & range & $13.04-36.92$ & $31.06-121.08$ & $58.03-167.50$ & $89.5-208.58$ & $89.8-215.61$ & $165.76-527.68$ \\
\hline & {$[\mathrm{g}]$} & mean $\pm \mathrm{SE}$ & $27.6 \pm 2.78$ & $57.3 \pm 3.14$ & $85.0 \pm 4.74$ & $141.1 \pm 8.64$ & $159.4 \pm 17.0$ & $276.3 \pm 31.32$ \\
\hline \multirow{4}{*}{ Female } & fork length & range & $10.8-11.6$ & $12.6-16.3$ & $14.0-25.0$ & $14.9-24.4$ & $16.3-26.3$ & $23.1-27.2$ \\
\hline & {$[\mathrm{cm}]$} & mean $\pm \mathrm{SE}$ & $11.2 \pm 0.40$ & $14.5 \pm 0.31$ & $17.9 \pm 0.56$ & $20.5 \pm 0.47$ & $23.7 \pm 0.54$ & $24.8 \pm 0.91$ \\
\hline & weight & range & $16.84-41.26$ & $29.06-85.34$ & $56.63-158.43$ & $75.10-178.72$ & $92.43-233.55$ & $179.32-534.13$ \\
\hline & [g] & mean $\pm \mathrm{SE}$ & $29.11 \pm 2.79$ & $51.67 \pm 3.79$ & $84.09 \pm 7.49$ & $119.66 \pm 7.07$ & $174.75 \pm 11.07$ & $350.40 \pm 42.83$ \\
\hline \multirow{4}{*}{ Both sexes } & fork length & range & $9.8-11.6$ & $11.6-16.3$ & $13.0-26.6$ & $14.1-24.4$ & $16.3-26.3$ & $23.1-27.2$ \\
\hline & {$[\mathrm{cm}]$} & mean $\pm \mathrm{SE}$ & $11.5 \pm 0.32$ & $15.0 \pm 0.19$ & $18.4 \pm 0.22$ & $20.6 \pm 0.30$ & $23.5 \pm 0.43$ & $25.0 \pm 0.35$ \\
\hline & weight & range & $13.04-41.26$ & $29.06-121.08$ & $56.63-167.50$ & $75.10-208.58$ & $89.8-233.55$ & $165.76-534.13$ \\
\hline & {$[\mathrm{g}]$} & mean $\pm \mathrm{SE}$ & $28.37 \pm 1.92$ & $55.54 \pm 2.47$ & $84.63 \pm 4.09$ & $128.94 \pm 5.69$ & $169.65 \pm 9.19$ & $225.62 \pm 11.93$ \\
\hline
\end{tabular}

$\mathrm{SE}=$ standard error of the mean. 
Age-length key of Barbus pectoralis from Kemer Reservoir

Table 2

\begin{tabular}{|c|c|c|c|c|c|c|c|}
\hline \multirow{2}{*}{$\begin{array}{l}\text { Fork length } \\
{[\mathrm{cm}]}\end{array}$} & \multicolumn{6}{|c|}{ Age group } & \multirow[b]{2}{*}{ Total } \\
\hline & $1+$ & $2+$ & $3+$ & $4+$ & $5+$ & $6+$ & \\
\hline 9 & 2 & & & & & & 2 \\
\hline 11 & 9 & 1 & & & & & 10 \\
\hline 13 & 7 & 18 & & & & & 25 \\
\hline 15 & & 32 & 8 & & & & 40 \\
\hline 17 & & 14 & 29 & 5 & & & 48 \\
\hline 19 & & & 11 & 13 & 3 & & 27 \\
\hline 21 & & & 4 & 16 & 7 & & 27 \\
\hline 23 & & & & 3 & 7 & 4 & 14 \\
\hline 25 & & & & & 4 & 8 & 12 \\
\hline 27 & & & & & & 1 & 1 \\
\hline $\mathrm{n}$ & 18 & 65 & 52 & 37 & 21 & 13 & 206 \\
\hline$\% n$ & 8.7 & 31.6 & 25.2 & 18.0 & 10.2 & 6.3 & 100 \\
\hline FL & $11.5 \pm 0.32$ & $15.0 \pm 0.19$ & $18.4 \pm 0.22$ & $20.6 \pm 0.30$ & $23.5 \pm 0.43$ & $25.0 \pm 0.35$ & $18.5 \pm 3.80$ \\
\hline $\mathrm{W}$ & $28.37 \pm 1.92$ & $55.54 \pm 2.47$ & $84.63 \pm 4.09$ & $128.94 \pm 5.69$ & $169.65 \pm 9.19$ & $225.62 \pm 11.93$ & $96.06 \pm 4.19$ \\
\hline Males & 9 & 45 & 31 & 16 & 7 & 9 & 117 \\
\hline Females & 9 & 20 & 21 & 21 & 14 & 4 & 89 \\
\hline $\mathrm{M}: \mathrm{F}$ & $1: 1.00$ & $1: 0.44$ & $1: 0.68$ & $1: 1.31$ & $1: 2.00$ & $1: 0.44$ & $1: 0.76$ \\
\hline
\end{tabular}

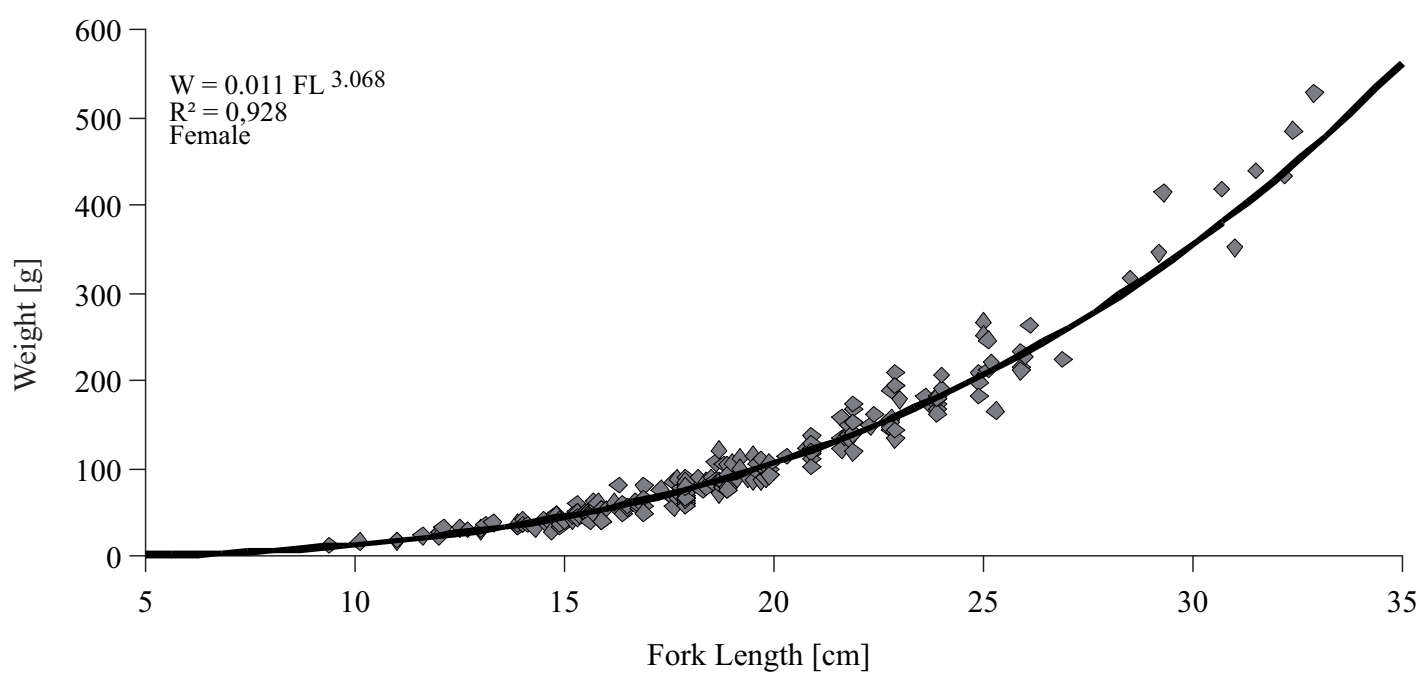

Fig. 2. Relation between fork length and weight of female Barbus pectoralis $(n=89)$ from Kemer Reservoir

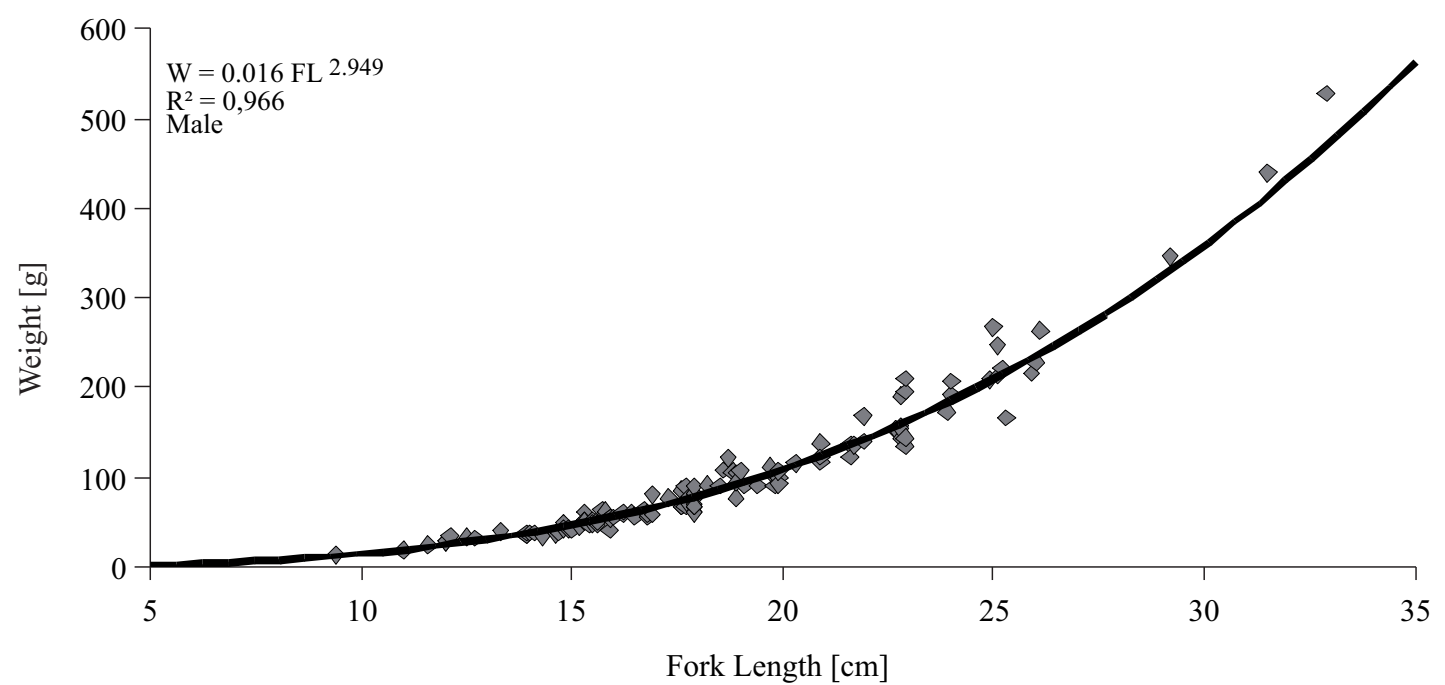

Fig. 3. Relation between fork length and weight of male Barbus pectoralis $(n=117)$ from Kemer Reservoir 


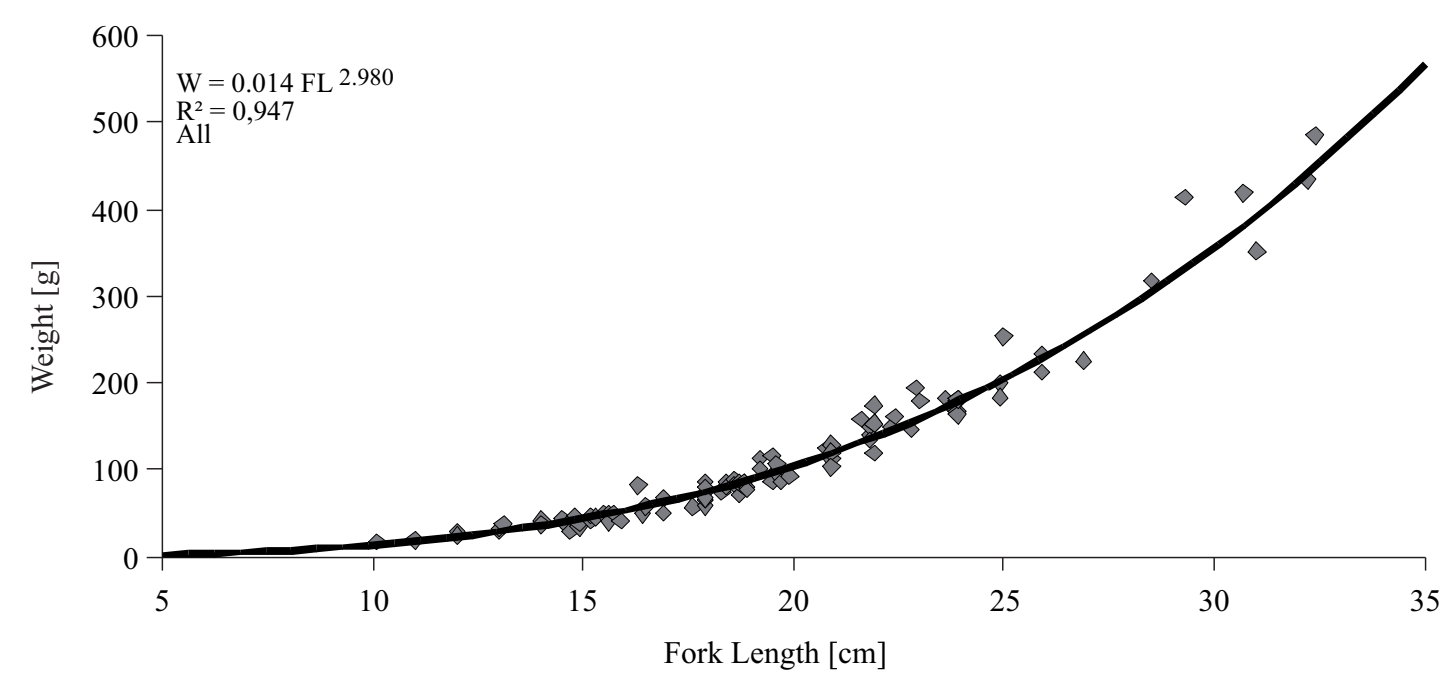

Fig. 4. Relation between fork length and weight of combined sexes of Barbus pectoralis $(n=206)$ from Kemer Reservoir

$K=0.161$ year $^{-1}$ and $t_{0}=-1.328$ years for females $\left(n=5, r^{2}=0.886\right), L_{\infty}=34.7(\mathrm{SE}=0.26) \mathrm{cm}, W_{\infty}=225.28$ $(\mathrm{SE}=31.83) \mathrm{g}, K=0.163 \cdot$ year $^{-1}$ and $t_{0}=-1.620$ years for males $\left(n=5, r^{2}=0.817\right)$ and $L_{\infty}=35.5(\mathrm{SE}=0.17)$ $\mathrm{cm}, W_{\infty}=232.15(\mathrm{SE}=32.20) \mathrm{g}, K=0.167 \cdot$ year $^{-1}$ and $t_{0}=-1.319$ years for all specimens $\left(n=5, r^{2}=0.804\right)$ (Figs. 5, 6). The values of $L_{\infty}$ and $W_{\infty}$ of females was higher than those of males, but there was a no significant difference between the growth parameters of males and females $\left(L_{\infty}: t=1.587<t_{0.05,204}=1.97, W_{\infty}: t=0.189<\right.$ $\left.t_{0.05,204}=1.97\right)$.

The growth performance index $\left(\varphi^{\prime}\right)$ was found to be 2.32 for combined sexes and 2.29, and 2.31 for males and females, respectively.

The condition factor was calculated as $1.272-1.367$ for males, and 1.337-1.423 for females.

\section{DISCUSSION}

The maximum estimated age was 6 years while Balık (1980) refers maximum age of 7 years in the Gediz River. Six and 8 years of age were reported from the Keban Reservoir in 1978 and 1979, respectively (Çolak 1982). Ergene (1998) reported a maximum age of 7 years in the Goksu River, while İkiz et al. (1998) found the maximum age of 5 years from the Aksu River. In the Avsar Reservoir the maximum age was 6 years (Topkara and Balık 2004). The age groups found for Kemer Reservoir population were consistent compared to other B. pectoralis populations described by Topkara and Balık (2004) and Çolak (1982; in first year).

In this study males were dominant. A similar situation has been reported by Balık (1980) (gill nets and cast nets) and İkiz et al. (1998) (electrofishing). However, Çolak (1982) (gill nets), Ergene (1998) (gill nets and cast nets), and Topkara and Balık (2004) (gill nets) found females to be more numerous than males. There tends to be a surplus of males on the spawning grounds in some species, because the males remain there longer or because the males shed mature sperm gradually. The females usually leave the spawning grounds more rapidly, which also may be considered as an adaptation facilitating preservation of the females or more rapid recovery of gonads, which results in an increased population. Males usually predominate in the younger groups because they mature earlier but live less long (Nikolsky 1969).

The growth of bassan barbel in Kemer reservoir was isometric $(b=2.98)$ in contrast to similar to those inhabiting in Gediz River $(b=2.85)$ (Balık 1980), Aksu River $(b=2.89)$ (İkiz et al. 1998), Avsar reservoir $(b=2.81)$ (Topkara and Balık 2004), and Kemer reservoir ( $b=3.14$, $t$-test $=2.375, P<0.05)$ Özcan (2008). The $b$ values of $L-W$ relations is known to vary according to age, maturity, and sex (Dulčić and Kraljević 1996). Geographic location and associated environmental conditions, such as seasonality (date and time of capture), stomach fullnes, disease and parasite loads (Le Cren 1951, Ricker 1975, Bagenal and Tesch 1978, Erkoyuncu 1995), can also affect the value of $b$.

The $L_{\infty}$ and $W_{\infty}$ values were calculated as $34.7 \mathrm{~cm}$ and $225.28 \mathrm{~g}$, respectively for males and $35.7 \mathrm{~cm} 238.00 \mathrm{~g}$, respectively for females (Figs.5, 6). The values of $L_{\infty}$ and $W_{\infty}$ of females was higher than those of males, but there was a no significant difference in the growth parameters between sexes $(P>0.05)$. Topkara and Balı (2004) reported also similar differences. The $L_{\infty}$ and $W_{\infty}$ values for the whole population were $35.5 \mathrm{~cm}$ and $232.15 \mathrm{~g}$, and these values were similar to the those reported by Topkara and Balık (2004), but different from those reported by İkiz et al. (1998) (Table 3). The differences in growth between regions can be attributed to the difference in the size of the largest individual sampled in each area.

Ergene (1998) and İkiz et al. (1998) report higher values for the condition coefficient (1.47-1.61 and 1.121-1.667 respectively), while Balık (1980) and 


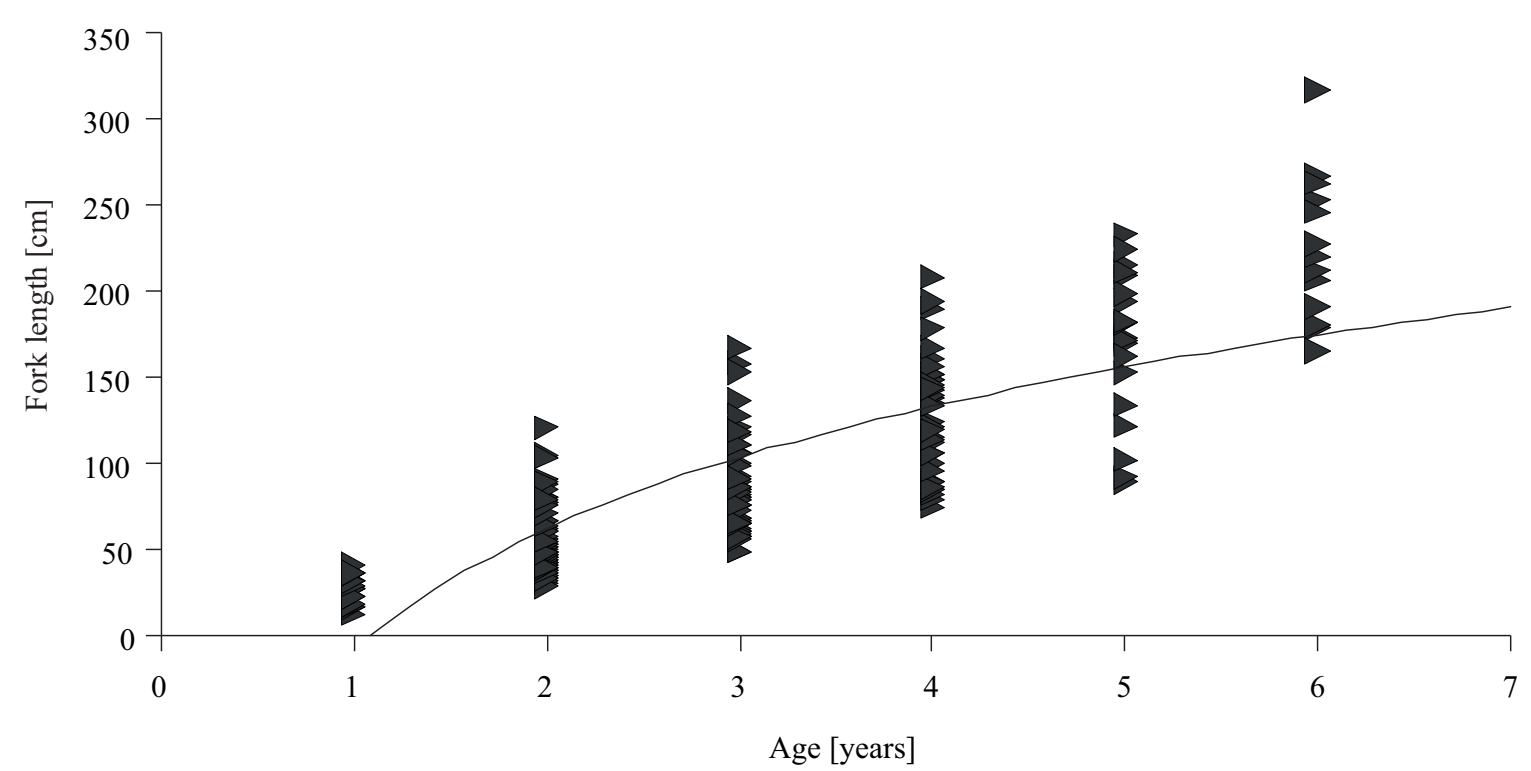

Fig. 5. Relation between fork length and age for combined sexes of Barbus pectoralis from Kemer Reservoir

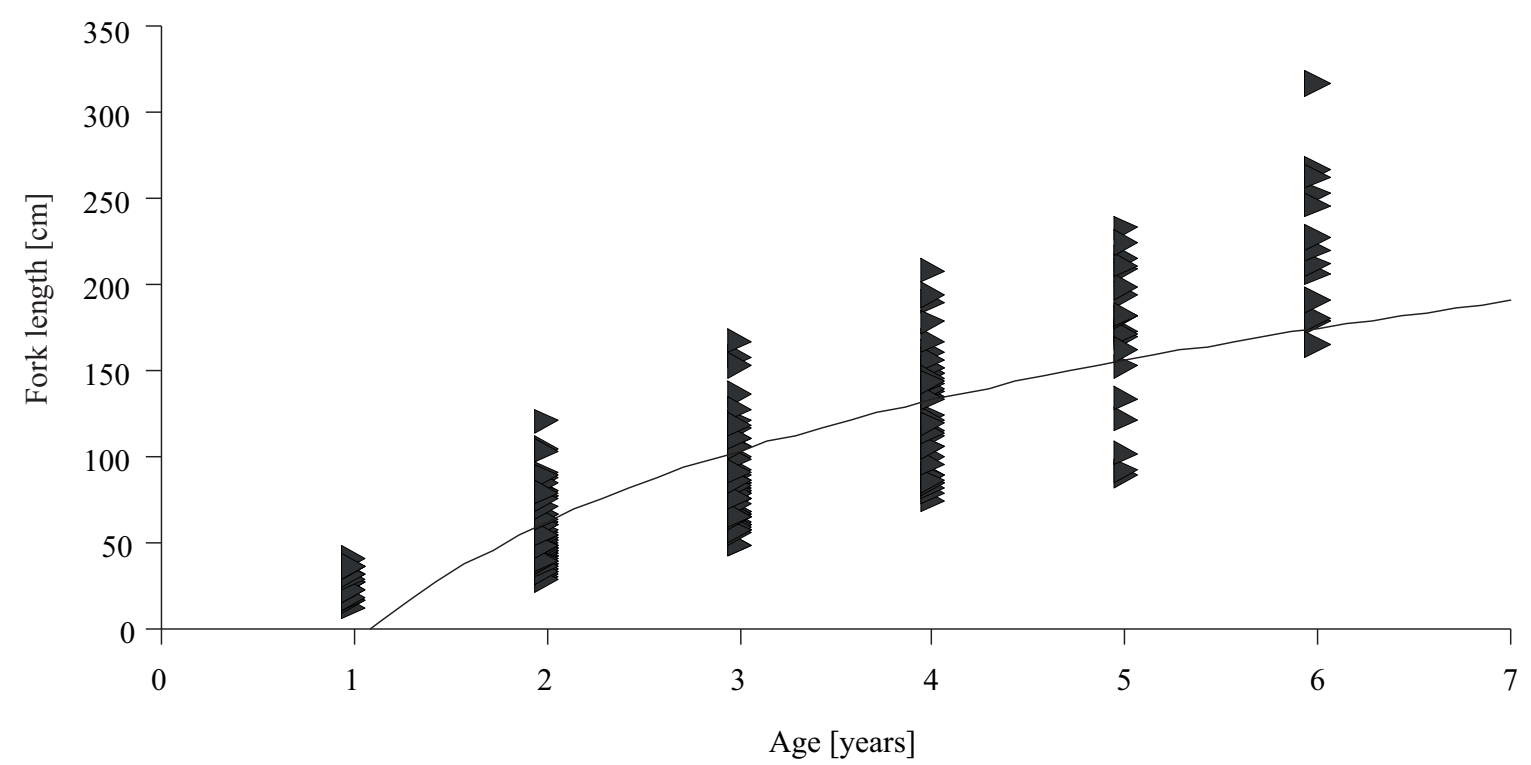

Fig. 6. Relation between weight and age for combined sexes of Barbus pectoralis from Kemer Reservoir

Table 3

Various growth parameter estimates of Barbus pectoralis from Kemer Reservoir

\begin{tabular}{|c|c|c|c|c|c|c|c|}
\hline $\begin{array}{l}L \infty \\
(\mathrm{FL})[\mathrm{cm}]\end{array}$ & $\begin{array}{l}W \infty \\
{[\mathrm{g}]}\end{array}$ & $\begin{array}{c}K \\
{\left[\text { year- }^{-1}\right]}\end{array}$ & $\begin{array}{c}t_{0} \\
\text { [years[ }\end{array}$ & $F L_{\min }-F L_{\max }$ & $n$ & Sex & Author \\
\hline 51.74 & 1623.38 & 0.055 & -3.909 & $6.4-22.5$ & 364 & both & $\begin{array}{l}\text { İkiz et al. (1998) } \\
\text { Aksu River }\end{array}$ \\
\hline $\begin{array}{l}36.22 \\
27.03 \\
35.33\end{array}$ & $\begin{array}{c}607.28274 .79 \\
562.80\end{array}$ & $\begin{array}{l}0.264 \\
0.534 \\
0.300\end{array}$ & $\begin{array}{l}-1.121 \\
-0.730 \\
-0.852\end{array}$ & $12.7-28.6$ & $\begin{array}{l}375 \\
247 \\
128\end{array}$ & $\begin{array}{c}\text { both } \\
\text { male } \\
\text { female }\end{array}$ & $\begin{array}{c}\text { Topkara and Balık (2004) } \\
\text { Avsar Reservoir }\end{array}$ \\
\hline $\begin{array}{l}35.5 \\
34.7 \\
35.7\end{array}$ & $\begin{array}{l}232.15 \\
225.28 \\
238.00\end{array}$ & $\begin{array}{l}0.167 \\
0.163 \\
0.161\end{array}$ & $\begin{array}{l}-1.319 \\
-1.620 \\
-1.328\end{array}$ & $9.8-27.2$ & $\begin{array}{r}206 \\
117 \\
89\end{array}$ & $\begin{array}{c}\text { both } \\
\text { male } \\
\text { female }\end{array}$ & $\begin{array}{l}\text { Presently reported study } \\
\text { Kemer Reservoir }\end{array}$ \\
\hline
\end{tabular}


Topkara and Balık (2004) mention almost similar with the present study values (1.142-1.315 and 1.315-1.481, respectively). Variation in the condition factor of fish may be indicative of food abundance, adaptation to the environment and gonadal development (King 1995).

Our study provides some important information on the age and growth of $B$. pectoralis that would be useful for fishery biologist to propose adequate regulations for sustainable fishery management and conservation of this highly economic important fish species in Kemer Reservoir.

\section{ACKNOWLEDGEMENTS}

The present study was financially supported by Mustafa Kemal University (Project No: 04 M 1704). The authors thanks to the staff of the Hydrobiology of Department, Ege University for their help in collecting the material.

\section{REFERENCES}

Bagenal T.B., Tesch F.W. 1978. Age and growth. Pp.101-136. In: Bagenal T.B. (ed.) Methods for assessment of fish production in fresh waters. IBP Handbook, Blackwell Scientific Publications, London.

Balık S. 1980. Gediz Nehri'ndeki Barbus capito pectoralis Heckel, 1843 populasyonunun biyo-ekolojisi üzerine araştirmalar. [Bioecological investigations on Barbus capito pectoralis Heckel, 1843 population found in the Gediz River.] Pp. 245-259. In: TÜBİTAK VII Bilim Kongresi Çevre Araştırma Grubu Tebliğleri, 6-10 October 1980, Aydın, Turkey. [In Turkish.]

Chugunova N.I. 1963. Age and growth studies in fish. Israel Program for Scientific Translations, Jerusalem.

Coad B.W. 1991. Fishes of the Tigris-Euphrates basin: a critical checklist. Syllogeus 68: 1-49.

Çolak A. 1982. Keban Baraj gölü'nde bulunan balık stoklarının populasyon dinamiği. [Population dynamics of the fish stocks in Keban Reservoir.] Doğa Bilim Dergisi 6: 1-14. [In Turkish.]

Dulčić J., Kraljević M. 1996. Age, growth and mortality of damselfish (Chromis chromis L.) in the eastern middle Adriatic. Fisheries Research 22: 255-264. DOI: 10.1016/ /0165-7836(94)00318-Q.

Ergene S. 1998. Goksu Irmagi'nda yaşayan Barbus capito pectoralis' in Heckel, 1843 büyüme özellikleri. [Growth properties of Barbus capito pectoralis Heckel, 1843 living in Goksu River.] Pp. 503-513. In: Doğu Anadolu Bölgesi III. Su Ürünleri Sempozyumu, 10-12 June 1998, Erzurum, Turkey. [In Turkish.]
Erkoyuncu İ. 1995. Balıkçılık biyolojisi ve populasyon dinamiği. [Fisheries biology and population dynamics.] Ondokuz Mayis University Publications, Sinop. [In Turkish.]

Geldiay R., Balık S. 2007. Türkiye Tatlısu Balıkları. [Freshwater fishes of Turkey.] Ege Üniversitesi, Su Ürünleri Fakültesi Yayınları, Izmir, Turkey. [In Turkish.]

Íkiz R., Becer Z.A., Gümüş E., Gülyavuz H. 1998. Aksu Çayı'nda yaşayan Barbus capito pectoralis Heckel, 1843 populasyonunun bazı büyüme özellikleri. [Some of the growth proporties of Barbus capito pectoralis Heckel, 1843 population in the Aksu River.] Pp. 171-186. In: Doğu Anadolu Bölgesi III. Su Ürünleri Sempozyumu, 10-12 June 1998, Erzurum, Turkey. [In Turkish.]

King M. 1995. Fisheries biology, assessment and management. Fishing News Books, Oxford, England.

Le Cren E.D. 1951. The length-weight relationship and seasonal cycle in gonad weight and condition in the perch (Perca fluviatilis). Journal Animal Ecology 20: 201-219.

Nikolskii G.V. 1969. Theory of fish population dynamics. (Translated by. J.E.S. Bradley), Oliver and Boyd, Edinburg.

Özcan G. 2008. Length-weight relationships for seven freshwater fishes caught in Kemer reservoir, Turkey. Journal of Applied Ichthyology 24: 337-338. DOI: 10.1111/j.1439$-0426.2007 .01054 . x$.

Özyalin S. 2007. Kemer Baraj Gölü (Aydın) fitoplanktonunun incelenmesi. [Investigation for phytoplankton of the Kemer Dam Lake (Aydın).] MSc Theis. Ege Üniversitesi Fen Bilimleri Enstitüsü, Izmir, Turkey. [In Turkish.]

Pauly D., Munro J.L. 1984. Once more on the comparison of growth in fish and invertebrates. ICLARM Fishbyte 2: 21.

Ricker W.E. 1975. Computation and interpretation of biological statistics of fish populations. Bulletin of the Fisheries Research Board of Canada 191: 1-382.

Topkara E.T., Balık S. 2004. Avşar Baraj Gölü’ndeki (Sarıöl, Manisa, Türkiye) Bıyıklı Balık (Barbus capito pectoralis Heckel, 1843) populasyonunun biyolojik yönden incelenmesi. [Biological investigation of barbel fish (Barbus capito pectoralis Heckel, 1843) population in Avsar Dam Lake (Sarıgol, Manisa, Turkey).] Ege Üniversitesi Su Ürünleri Dergisi $=$ Ege University Journal of Fisheries and Aquatic Sciences 21 (3-4): 253-256. [In Turkish.]

Received: 25 April 2008

Accepted: 14 January 2009 Published electronically: 20 May 2009 